B.V.Vynohradov, Dr. Sc. (Tech.), Prof., orcid.org/0000-0002-9600-0739,

D. O. Fedin, Cand. Sc. (Tech.), Assoc. Prof., orcid.org/0000-0001-6037-1178,

V.V.Ved,

orcid.org/0000-0002-2391-6463
State Higher Educational Institution "Ukrainian State University of Chemical Technology”, Dnipro, Ukraine, e-mail: borvvin@ gmail.com; tm.i.sm.master@gmail.com; 251277ved@gmail.com

\title{
IMPACT OF FLEXIBILITY OF SUPPORT ON GEAR MESH DYNAMICS
}

Purpose. Development of a mathematical model of gear mesh which takes into account flexibility of a pinion support for studying the influence of lateral vibrations on gear dynamics as a whole.

Methodology. The calculation model is designed using lumped-parameters method. The research on dynamics of the system is performed by methods of the theory of oscillations of two degree of freedom systems. Using the approximate method of theory of oscillations and algebra, vibrational amplitude of the system is defined. The results of numerical integration of dynamic equations are compared to the experimental data.

Findings. State-of-the-art review on gear mesh models taking into account coupling effect of pinion torsional and lateral vibrations is performed. Based on the lumped-parameters method, an analytical model for calculating dynamics of gear mesh with flexible support is developed. The amplitude-frequency response of open gearing of a tumbling mill MSHRGU $4500 \times 6000$ is studies taking into account flexibility of a pinion shaft and bearing parts. It is shown that torsional vibrations of a pinion and lateral vibrations of a power unit have a coupling effect. The models of highly loade gearing give values of natural frequencies with a significant error. A range of possible force resonance in a power unit of tumbling mill open gearing is defined. Causes of excessive vibroactivity of mechanical systems of drives of certain mills and increasing vibroactivity when in operation are established. It is shown that amplification of vibroactivity of a tumbling mill power unit due to intermittent action of forces with gearing frequency is improbable. Rational techniques of reducing vibroactivity of existing mills due to lubrication and increasing hardness of working face of gear teeth are defined.

Originality. Methods for defining resonance range of gear mesh which consider a coupling effect of pinion torsional vibrations and pinion shaft lateral vibrations are developed.

Practical value. The range of possible force resonance in a power unit of tumbling mill MSHRGU $4500 \times 6000$ open gearing is defined.

Keywords: gear mesh, natural frequency, vibration activity, resonance, tumbling mill

Introduction. There is no universal model of gearing dynamics because physical processes which accompany the process of meshing are complicated and various. Instead, there is a wide variety of models which are different by both physical phenomena considered and assumptions accepted.

Often, while considering gear dynamics, one neglects shaft flexibility of gears and flexibility of bearings. This assumption is acceptable if gear is assembled on relatively short shaft with big diameter (Ozguven, Houser). However, this assumption is unacceptable if gearing is high-speed or assembled on support whose stiffness is close to the stiffness of gearing. In case of coincidence of natural frequencies of support and gearing, it is possible that torsional and transverse oscillation affect and intensify each other.

Drives of large-size gearings, for example, drives of open gearings of tumbling mills are complicated vibrational systems which consist of partial systems with their own vibrational properties. Among these partial systems gearing is the most important. Gearing is the source of periodically varying loads which affect the partial system of the drive. In case of coincidence of load frequency and natural frequency resonance phenomena are possible. The resonance brings about vibrational activity of drive and its early fatigue.

Literature review. Development of drive structures follows the path of increasing of specific capacity of machines under conditions of increasing of requirements to accuracy and reliability of machines. As a result, the elements of structures undergo too big dynamic loads.

Gearing is the structure whose mechanical system consists of three dimensional oriented inertial, flexible and dissipative elements [1]. It is very important for analyzing and prediction of vibrational activity to create a reliable dynamic model of gearing which considers transfer of energy of oscillation between parts.

According to recent works concerning the present matter, there is a whole class of models of gearing - rotor dynamics

(C) Vynohradov B. V., Fedin D. O., Ved V.V., 2019 models with gearing - which consider the flexibility of parts of drive to a variable degree.

Schwibinger and Nordmann [2] considered the dynamics of gearing of rotor system taking into account transverse flexibility of bearings and shafts. They showed that the principle of gearing conditions strong interrelation between torsional and transverse oscillation. The torque applied to pinion is passing to gear by meshing forces. That is why the torque causes transverse load and bending moment. Torsional and transverse displacements at coupled gears have kinematic relation with each other

$$
r_{1} q_{1}+q_{3}=r_{2} q_{2}+q_{4}
$$

where $r_{1} q_{1}$ and $r_{2} q_{2}$ are virtual displacements during the torsion; $q_{3}, q_{4}$ are virtual displacements in transverse direction. Numerical solution of differential equations of motion showed that torsional and transverse oscillations are essentially coupled. Use of classic methods of determination of natural frequencies which do not consider the interdependence of torsional and transverse oscillation could cause significant mistakes during gears design.

Seshendra Kumar Venkat Karri, Sree Krishna Sundara Siva Rao Bollapragada [3] considered a similar problem with consideration of transverse flexibility of supports in vertical and horizontal directions. For the purpose of investigation of torsional and transverse oscillation the dynamic parameters of the considered system were selected to be very close. Torsional and transverse natural oscillations under the action of unbalanced masses were investigated. It is shown that torsional and transverse oscillations interact with each other. Two critical values of shaft rotation velocity were detected instead of one value according to the model which considers only torsional vibration. Intensity of interaction depends of proximity of natural frequencies of torsional and transverse oscillations. Xue and Howard [4] considered a similar problem and showed that flexibility of supports of gear shafts under load results in changing of nature of gear mesh stiffness oscillation. Kurushin, Balyakin and Ossiala have dealt with an analytical solution for the simple model dynamics of gears on elastic supports [5]. 
The analysis of literary data showed lack of research studies devoted to coupled vibration at heavy loaded gearings. Stiffness of parts is determined by approximate estimations or varying for the purpose of imitation of resonance modes. At the same time, the precision of estimation of stiffness significantly affects the accuracy of the model [6].

The purpose of present study is creating of a reliable model of gearing which considers the flexibility of supports for the purpose of investigation of impact of transverse oscillation on gearing and drive dynamics on the whole.

Statement of the problem. For the purpose of determination of impact of torsional flexibility of supports on heavyloaded gearing dynamics the equivalent model of gearing is considered (Fig. 1).

It is accepted that a gear has a relatively big mass and there are no meshing errors. Then meshing would be presented as a flexible connection with equivalent linear stiffness $C, \mathrm{~N} / \mathrm{m}$. Pinion is absolutely rigid and is placed on a flexible support with equivalent linear stiffness $C_{1}, \mathrm{~N} / \mathrm{m}$. Under the action of drive torque $M$, the pinion rotates in the direction of drive torque with rotational displacement $\varphi$. As a result of gear mesh and support flexibility, the pinion drifts in the direction which is opposite to the direction of meshing force (horizontal displacement of the pinion is neglected). Force of flexibility balances the pinion.

Thereby, gear mesh represents a one-mass system with two degrees of freedom and its dynamics, neglecting dumping, could be described by two ordinary differential equations

$$
\begin{gathered}
I \ddot{\varphi}=-C r(\varphi r-x) ; \\
m \ddot{x}=-C_{1} x+C(\varphi r-x),
\end{gathered}
$$

where $I$ is the moment of inertia of the pinion, $\mathrm{kg} \cdot \mathrm{m}^{2} ; m$ is the mass of the shaft gear, $\mathrm{Kg} ; \varphi$ is an angle of pinion rotation, rad; $C$ is equivalent linear stiffness of gear mesh, $\mathrm{N} / \mathrm{m} ; C_{1}$ is equivalent linear stiffness of the support of the pinion, $\mathrm{N} / \mathrm{m} ; r$ is the radius of the basic circle of the pinion, $\mathrm{m} ; x$ is vertical displacement, $\mathrm{m}$.

Results. Let us build a general solution of the equations $(1,2)$ using the method proposed by Timoshenko [7]. Equations $(1,2)$ are the equations with constant coefficients. Let us assume a particular solution as

$$
\begin{aligned}
& \varphi=A_{1} \sin (p t+\alpha) ; \\
& x=A_{2} \sin (p t+\alpha),
\end{aligned}
$$

where $A_{1}, A_{2}$ are unknown amplitudes; $p$ is angular frequency, $\mathrm{s}^{-1} ; t$ is time, $\mathrm{s} ; \alpha$ is a vibration phase.

Substituting $(3,4)$ to $(1,2)$ we get a system of algebraic equations, which are homogeneous relatively to amplitudes $A_{1}$ and $A_{2}$

$$
\begin{gathered}
-I p_{1}^{2} A_{1}+C r^{2} A_{1}+\frac{C r}{I} A_{2}=0 \\
-p_{2}^{2} A_{2}+\frac{C_{1}}{m} A_{2}+\frac{C}{m} A_{2}-\frac{C r}{m} A_{1}=0 .
\end{gathered}
$$

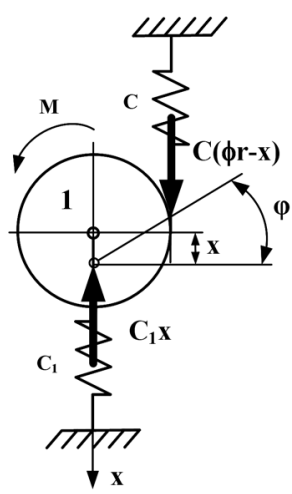

Fig. 1. Design model of gear mesh:

1 - pinion; $C$ - mesh stiffness; $C_{1}-$ stiffness of the support; $M-$ torque; $x$ - linear coordinate; $\varphi$ - angle of rotation
Amplitudes $A_{1}$ and $A_{2}$ cannot be equal to zero during vibrations. Therefore, the determinant, composed of coefficients of the system of equations $(5,6)$, has to be equal to zero

$$
\left|\begin{array}{cc}
\frac{C r^{2}}{I}-p^{2} & \frac{C r}{I} \\
-\frac{C r}{m} & \frac{C+C_{1}}{m}-p^{2}
\end{array}\right|=0,
$$

which can be expanded with a result

$$
a p^{4}+b p^{2}+c=0,
$$

where

$$
a=1 ; \quad b=-\left(\frac{C r^{2}}{I}+\frac{C+C_{1}}{m}\right) ; \quad c=\frac{C r^{2}}{I m}\left(C_{1}+2 C\right) .
$$

The roots of the (7) are of the form

$$
p_{1,2}^{2}=\frac{C r^{2}}{2 I}+\frac{C_{1}+C}{2 m} \pm \sqrt{\frac{\left(\frac{C r^{2}}{I}+\frac{C+C_{1}}{m}\right)^{2}}{4}-\frac{C r^{2}}{I m}\left(C_{1}+2 C\right)} .
$$

It is obvious from expression (8) that the system has got two natural frequencies of vibrations $p_{1}$ and $p_{2}$ in contrast to the system without flexible support, which has got only one natural frequency

$$
k=\sqrt{\frac{C r^{2}}{I}} .
$$

For instance, let us consider the calculation of natural frequencies of open gearing of tumbling mill MSHRGU $4500 \times 6000$. Gear meshes of tumbling mills are unique because of their size and getting big static and dynamic loads. Unbalanced forces, which have been induced by periodical process of engagement and by impacts due to inaccuracies, are the source of periodic effect on the mechanical drive system. In case of coincidence of frequencies of impact and natural frequencies of drive system the rise of vibration activity, dynamic loads and premature damage are possible.

Table shows the main parameters of gear mesh concerned. Fig. 2 shows the scheme of the shaft gear support.

The pinion 1 is adjusted at shaft 2 , which is mounted at supports 4 by bearings 3 . Supports of the shaft are suggested to be absolutely rigid.

Determination of mesh stiffness, $C$, is a complicated problem. It is known that stiffness of a pair of teeth consists of contact stiffness, banding stiffness and stiffness of a tooth root. The components do not have an accurate form, thereby can be determined by the finite element method owing to the ability to consider the strain of involute tooth, rim and web of arbitrary design as well as contact strain. In the present investigation mesh stiffness is determined by the finite element analysis using a technique stated in the article [6]. This calculation technique is the basis of the design of a 3-D model of mesh, assigning of mechanical properties of constructional materials and boundary conditions, the design of calculating mesh, solving a contact problem using the finite element method with controlling convergence, calculating maximal displacement of points at the line of contact of the tooth.

$$
C=\frac{F_{n}}{\delta}
$$

where $F_{t}$ is tangential force, $\mathrm{kN} ; \alpha_{w}$ is a pressure angle, deg.

Determination of stiffness of bearings is a complicated problem also because its value depends on significant quantity of factors, which are not known beforehand. For estimation of stiffness of bearings, , the technique for calculation of rolling conical double-row bearing is used (GOST 6364-78) which takes into account their seatings on the shaft (Beizelman) [8]. 
Table

Main parameters of gar mesh of a tumbling mill MSHRGU $4500 \times 6000$

\begin{tabular}{|l|l|c|c|}
\hline \multirow{2}{*}{\multicolumn{1}{|c|}{ Parameter }} & \multirow{2}{*}{ Notation } & \multicolumn{2}{c|}{ Value } \\
\cline { 3 - 4 } & & Pinion & Wheel \\
\hline Number of teeth & $z$ & 46 & 252 \\
\hline Face width & $b, \mathrm{~mm}$ & 1000 & 1000 \\
\hline Pitch diameter & $d, \mathrm{~mm}$ & 1150 & 6300 \\
\hline Pressure angle & $a,^{\circ}$ & 20 \\
\hline Normal module & $m, \mathrm{~mm}$ & \multicolumn{2}{|c|}{25} \\
\hline Axis distance & $a_{w}, \mathrm{~mm}$ & 3725 \\
\hline Pinion rotation velocity & $n_{1}, \mathrm{rpm}$ & \multicolumn{2}{|c|}{75} \\
\hline Torque on pinion & $M, \mathrm{kN} \cdot \mathrm{m}$ & \multicolumn{2}{|c|}{509.3} \\
\hline Reduction rate & $u$ & \multicolumn{2}{|c|}{5.5} \\
\hline Moment of inertia of pinion & $I, \mathrm{~kg} \cdot \mathrm{m}^{2}$ & \multicolumn{2}{|c|}{$1.3 \cdot 10^{3}$} \\
\hline Mesh stiffness [3] & $C, \mathrm{~N} / \mathrm{m}$ & \multicolumn{2}{|c|}{$6.3 \cdot 10^{9}$} \\
\hline Stiffness of support & $C_{1}, \mathrm{~N} / \mathrm{m}$ & $6.5 \cdot 10^{10}$ \\
\hline Reduced mass of pinion and shaft & $m, \mathrm{~kg}$ & $9.0 \cdot 10^{3}$ \\
\hline
\end{tabular}

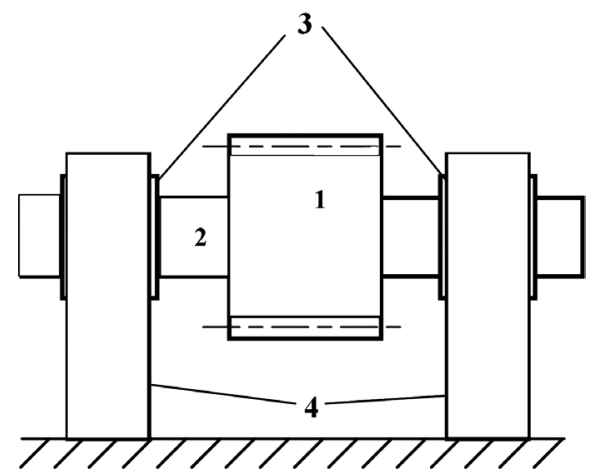

Fig. 2. Scheme of the pinion system:

1-pinion; 2-shaft; 3 - bearings; 4-supports

Radial stiffness of the bearing in the unit is

$$
C_{1}=\frac{F_{r}}{d_{r}}
$$

where $F_{r}$ is radial load, $\mathrm{kN} ; d_{r}$ is radial compliance of the bearing under the load, $\mathrm{m}$.

Radial compliance, in turn, consists of the radial compliance of the most loaded roll with its groove and the radial compliance of the bearing ring in the contact with the seat surfaces of shaft and body

$$
d_{r}=d_{r 1}+d_{r 2},
$$

where $d_{r 1}$ is radial compliance of the most loaded roll with its groove, $\mathrm{m} ; d_{r 2}$ is radial compliance of the bearing ring in the contact with the seat surfaces of the shaft and body, $m$.

Radial compliance of the most loaded roll with its groove could be described as

$$
d_{r 1}=\beta d_{r 0}-\frac{G_{r}}{2}
$$

where $\beta$ is the factor, which takes into account the tightness or the gap in the bearing; $d_{r 0}$ is radial compliance of the most loaded roll with its groove with zero gap, $\mathrm{m} ; G_{r}$ is a radial gap, $\mathrm{m}$.

Radial compliance of the bearing ring in the contact with the seat surfaces of the shaft and body could be described as

$$
d_{r 2}=\frac{4 P k}{\pi d B}\left(1+\frac{d}{D}\right)
$$

where $k$ is the factor, which takes the values from 0.05 to 0.25 ; $d$ is the internal diameter of the bearing, $\mathrm{m}$; $D$ is the external diameter of the bearing, $\mathrm{m} ; B$ is the width of bearing, $\mathrm{m}$.

Radial compliance of the most loaded roll with its groove with zero gap, in turn, could be determined by a standard nomogram or described as

$$
d_{r 0}=\frac{1.2 \cdot 10^{-3} \sqrt[4]{Q^{3}}}{\cos \alpha \sqrt{l}},
$$

where $Q$ is radial load, which is applied to the most loaded roll, $\mathrm{kN} ; \alpha$ is a contact angle in the rolling bearing, deg; $l$ is the length of the roll, $\mathrm{m}$.

Radial load, which is applied to the most loaded roll, could be described as

$$
d_{r 0}=\frac{5 F_{r}}{i \cdot z \cdot \cos \alpha}
$$

where $i$ is the quantity of the set of rolls; $z$ is the quantity of the rolls in the set; $\alpha$ is the contact angle.

The actual values of the majority of parameters mentioned above are difficult to determine. Furthermore, their actual values are sufficiently varying during operation. For the purpose of getting the guess value of bearing stiffness, the typical roll conical double groove bearing was considered. The parameters to be accepted are as follows: $\alpha=20^{\circ} ; I=2 ; z=10 ; l=$ $=0.2 \mathrm{~m} ; \beta=1$. The calculated value of radial stiffness of the bearing in the unit is $6.5 \cdot 10^{10} \mathrm{~N} / \mathrm{m}$.

If we substitute parameters of stiffness and inertia showed in table 1 to (7), we obtain natural frequencies $p_{1}=2.8 \cdot 10^{3}$ and $p_{2}=1.4 \cdot 10^{3} \mathrm{c}^{-1}$, which are natural frequencies of torsional and transverse vibrations of gear mesh. The value of $p_{2}$ differs from the corresponding value obtained with neglecting transverse vibration of gear mesh less than $6 \%$.

Fig. 3 shows time series of natural vibrations of the mechanical system during the period of time, equal to five periods of toothing. One can see that transverse vibration (curve 1) and torsional vibration (curve 2) have a cross-effect. Mutual modulation with carrier frequencies $p_{1}$ and $p_{2}$, which are calculated earlier, occurs.

For the purpose of determination of frequency response of the system let us assume that the system is under action of force, varying by the harmonic law

$$
Q=H \sin \omega t,
$$

where $H$ is amplitude, $\mathrm{N} ; \omega$ is the frequency of forced excitation, $\mathrm{s}^{-1}$.

In this case the differential equations of motion of the system can be represented as

$$
\begin{gathered}
I \ddot{\varphi}+C r(\varphi r-x)=-H r \sin \omega t ; \\
m \ddot{x}+C_{1} x-C(\varphi r-x)=-H \sin \omega t,
\end{gathered}
$$

while steady motion can be founded in the form

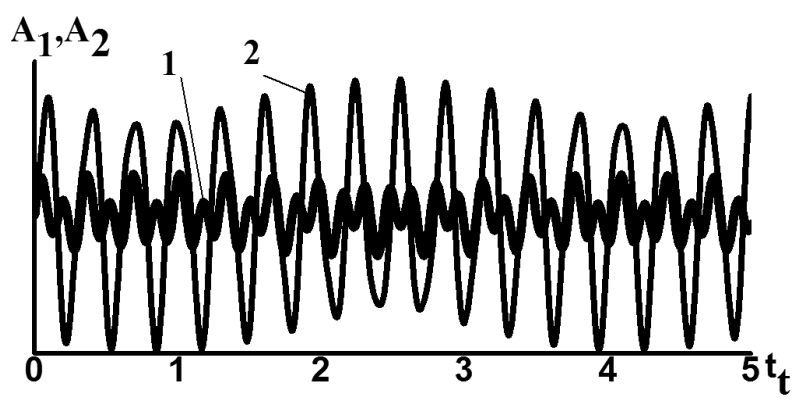

Fig. 3. Natural vibration of mechanical system of the gear mesh of a tumbling mill:

1 - vertical displacement of a pinion; 2 - torsional vibration of a pinion; $t_{t}$ - period of teeth coupling 


$$
\begin{aligned}
& \varphi=A_{1} \sin \omega t ; \\
& x=A_{2} \sin \omega t .
\end{aligned}
$$

Substituting $(11,12)$ into the system of equations $(9,10)$, we get a system of algebraic equations for determination of amplitudes of vibration

$$
\begin{gathered}
-I \omega_{1}^{2} A_{1}+C r^{2} A_{1}+C r A_{2}=-H r ; \\
-m \omega^{2} A_{2}+C_{1} A_{2}-C r A_{1}+C A_{2}=-H,
\end{gathered}
$$

from which we can get expressions for amplitudes $A_{1}$ and $A_{2}$

$$
\begin{aligned}
& A_{1}=\frac{-H r\left(\left(C+C_{1}\right)-m \omega^{2}\right)+H C r}{\left(C r^{2}-I \omega^{2}\right)\left(\left(C+C_{1}\right)-m \omega^{2}\right)-(C r)^{2}} ; \\
& A_{2}=\frac{-H\left(C r-m \omega^{2}\right)+H\left(C r^{2}-I \omega^{2}\right)}{\left(C r^{2}-I \omega^{2}\right)\left(\left(C+C_{1}\right)-m \omega^{2}\right)-(C r)^{2}} .
\end{aligned}
$$

Fig. 4 shows frequency response of the mechanical system of gear mesh taking into account the lateral vibration. It is shown that this system has two resonance ranges corresponding to forced frequencies, which are close to $p_{1}$ and $p_{2}$.

It is known that periodic engagement of gear teeth is the cause of appearance of periodic disturbing forces (Birger). The most essential component of that disturbance has frequency of teeth engagement. Owning to non-ideal sinusoidal form of disturbance and non-constant period of sequence of impulses, there could appear forces with frequency of alteration, which is multiple to frequency of teeth engagement.

The calculated value of the angular frequency of teeth engagement is $p_{z}=361 \mathrm{~s}^{-1}$. This value is by 3.9 times less than the natural frequency of torsional vibration $p_{2}$ and by 7.8 times less than the natural frequency of lateral vibration $p_{1}$. The ratio of calculated frequencies means that appearance of resonance vibration due to teeth engagement is improbable.

The open gearings of tumbling mills are relatively low-speed drives. The coincidence of natural and forced frequencies is more probable at more high-speed gearings, for example, reduction units of general and heavy machinery. In that case, the use of methods for determination of natural frequencies, which do not take into account mutual impact of torsional and lateral vibrations, could lead to significant errors of gearing design [2].

In spite of this, some drives of tumbling mills are very vibroactive. Fig. 5 shows experimental results of measurements of vertical vibration of a drive unit of a tumbling mill MRG $5500 \times 7500$.

Analysis of experimental data shows that vibration activity of a driving pinion depends on the value of kinematic excitation. The value of amplitude of kinematic excitation depends on values of deviations of gear mesh. Provided small runout of gear mesh the amplitudes of forced vibration are relatively small.

With intensive runout the fouling of active face of tooth appears, the engagement inaccuracy and vibroactivity arise

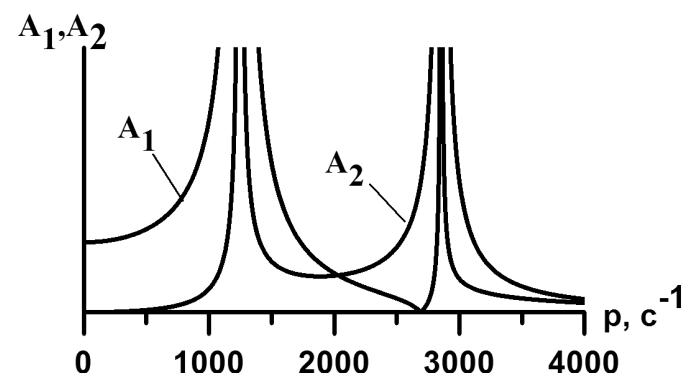

Fig. 4. Frequency response of the mechanical of gear mesh of a tumbling mill:

$A_{1}$ - the first amplitude; $A_{2}$ - the second amplitude; $p$ - angular frequency

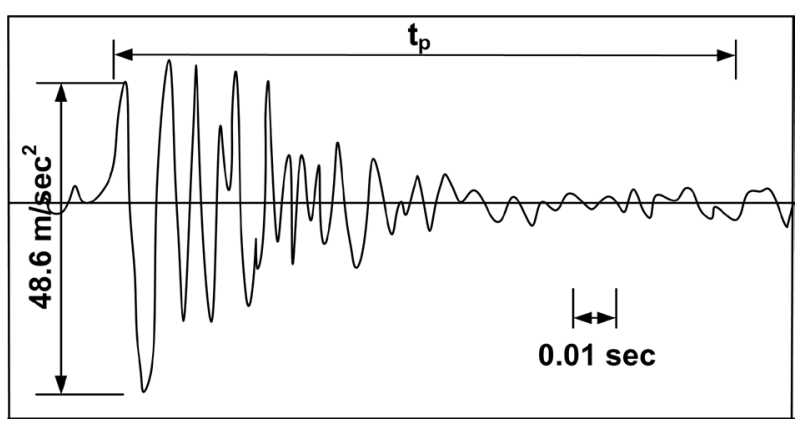

Fig. 5. Time history of vibration activity of driving assembly of a tumbling mill MRG $5500 \times 7500$ (vertical vibration of a running-in pinion during the start):

tp - period of rotation of the pinion

(Fig. 5). The change-out of a pinion and use of not running-in gear mesh lead to intensive vibration activity.

Reducing the intensity of wearing of open gearing can be provided by the reduction of pollution of lubricant by abrasive additives. In addition to application of different shielding shells, an application of special methods for lubrication and different types of lubricants, providing covering of the acting face by a thin layer of oil, leads to reducing of lubricant pollution.

One of the requirements to lubricants is allowance to form a thin layer on the acting faces of teeth and not to accumulate abrasive particles ingressing to lubricant from the environment. The thin layer of lubricant on the acting face of tooth does not hold large abrasive particles reducing the rate of abrasive runout of the gear mesh. Reduction of concentration of abrasive particles and additions by 1.5 times allows reducing the abrasive runout in 1.6 times. All mentioned above is confirmed by the experience of using the centralized lubricant system LINCOLN GmbH at Poltava Ore Mining and Processing Enterprise.

The extending of hardness of acting faces of the pinion and gear teeth up to $\mathrm{HB}_{1} 550-600, \mathrm{HB}_{2} 300$ by case hardening and following grinding is a determining factor for extending durability of open gearing. In this case the rate of runout of teeth of the pinion and gear are by 4.2 and 3.6 times correspondingly less than that of teeth of gearing with hardness up to $\mathrm{HB}_{1} 300$, $\mathrm{HB}_{2} 200$. It enables to run one pinion with gear without spared modes of running-in and eliminates high internal dynamic loads and vibroactivity of gear drive (Vinogradov).

Conclusions.

1. The physical and mathematical model of gear mesh which takes into account the flexibility of shaft and bearing unit dynamics is developed. The developed model allows determining dynamic parameters of system excluding resonant modes of mesh operation.

2. The analysis of dynamics of standard gear mesh of a tumbling mill is done. The analysis of dynamic response of the system allowed finding out that forced vibration, which is observed, occurs in a sub-resonant range. The amplitude of vibration is specified by the amplitude of distortion, which is induced by inaccuracies of gear mesh.

\section{References.}

1. Shpachuk, V. P. (2016). Effect of mutually amplifying action two coordinate shock loading in problems of dynamics of knots of machines. Naukovyi Visnyk Natsionalnoho Hirnychoho Universytetu, 6, 89-94.

2. Schwibinger, P., \& Nordmann, R. (n.d.). Optimization of a Reduced Torsional Model Using a Parameter Identification Procedure. Application of System Identification in Engineering, 525-542. DOI: 10.1007/978-3-7091-2628-8_16.

3. Seshendra Kumar Venkat Karri, \& Sree Krishna Sundara Siva Rao Bollapragada (2012). Influence of lateral vibrations on the whirling characteristics of gear-pinion rotor system. 
Journal of Vibration and Control, 18(11), 1624-1630. DOI: $10.1177 / 1077546311423064$

4. Xue, S., \& Howard, I. (2016). Dynamic modelling of flexibly supported gears using iterative convergence of tooth mesh stiffness. Mech. Syst. Signal Process., 1-25. DOI: 10.1016/j. ymssp.2016.04.030.

5. Kurushin, M., Balyakin, V., \& Ossiala, V. (2017). Investigation of the dynamics of gear systems with consideration of a pinion support flexibility. Procedia Engineering, 176, 25-36. DOI: 10.1016/j.proeng.2017.02.269.

6. Fedin, D. O., \& Vinogradov, B.V. (2018). Mechanical system dynamics of tumbling mill drives under steady-state operation. Scientific Journal of Silesian University of Technology, 99, 43-52. DOI: 10.20858/sjsutst.2018.99.4.

7. Timoshenko, S. (n.d.). Vibrations in engineering. Retrieved from http://booksshare.net/books/physics/timoshenko-sp/ 1985/files/kolebaniyavinjenernomdele 1985.pdf.

8. Beizelman, R., Tsypkin, B. V., \& Perel, L. Ya. (n.d.). Antifriction bearings. Retrieved from https://www.twirpx.com/ file/963853/

9. Ma, H., Pang, X., Feng, R., Song, R., \& Wen, B. (2015).

Fault features analysis of cracked gear considering the effects of the extended tooth contact. Engineering Failure Analysis, 48, 105-120. DOI: 10.1016/j.engfailanal.2014.11.018.

10. Temis, Y., Kozharinov, E., \& Kalinin, D. (2015). Simulation of Gear Systems with Dynamic Analysis. In Materials of The $14^{\text {th }}$ IFToMM World Congress, Taipei, Taiwan. DOI: 10.6567/IFToMM.14TH.WC.OS6.029.

\section{Вплив податливості опори на динаміку зубчастої передачі}

\section{Б. В. Виноградов, Д. О. Федін, В. В. Ведь}

Державний вищий навчальний заклад „Український державний хіміко-технологічний університет“, м. Дніпро, Україна, e-mail: borvvin@gmail.com; tm.i.sm.master@ gmail.com; 251277ved@gmail.com

Мета. Створення моделі зубчастої передачі, що враховує податливість опори шестерні, для дослідження впливу поперечних коливань на динаміку зубчастої передачі в цілому.

Методика. Розрахункова схема складена за допомогою метода зосереджених параметрів. Дослідження динаміки системи здійснюється методами теорії коливань систем із двома ступенями вільності. Із використанням наближених методів теорії коливань і алгебри визначені амплітуди коливань системи. Результати чисельного розрахунку рівнянь динаміки порівнюються з експериментальними даними.

Результати. Досліджено сучасний стан питання стосовно математичних моделей динаміки зубчастих передач, що враховують взаємодію крутильних і поперечних коливань. За допомогою методу зосереджених параметрів створена розрахункова схема задля розрахунку динаміки зубчастої передачі на податливій опорі. Досліджена амплітудно-частотна характеристика відкритої зубчастої передачі барабанного млина МШРГУ $4500 \times 6000$ з урахуванням податливості вала-шестерні й підшипників. Показано, що крутильні коливання шестерні й поперечні коливання приводного вузла мають взаємний вплив. Моделі динаміки високонавантажених зубчастих передач дають значення власних частот зі значною похибкою. Визначені області силового резонансу для відкритої зубчастої передачі барабанного млина. Визначені чинники підвищеної віброактивності механічних систем приводів деяких типів млинів і чинники зростання віброактивності із часом експлуатації. Показано, що підвищення віброактивності приводного вузла млина внаслідок періодичної дії сил, що діють із зубчастою частотою, малоймовірне. Визначені раціональні способи зменшення віброак- тивності існуючих млинів за рахунок змащення й підвищення твердості робочих поверхонь зубів шестерень

Наукова новизна. Розроблена методика визначення резонансних областей зубчастих передач з урахуванням взаємного впливу крутильних коливань шестерні й поперечних коливань опори шестерні.

Практична значимість. Визначені області можливого силового резонансу у приводному вузлі відкритої зубчастої передачі барабанного млина МШРГУ $4500 \times 6000$.

Ключові слова: зубчаста передача, власна частота, віброактивність, резонанс, барабанний млин

\section{Влияние податливости опоры на динамику зубчатой передачи}

\section{Б. В. Виноградов, Д. А. Федин, В. В. Ведь}

Государственное высшее учебное заведение „Украинский государственный химико-технологический университет“, г. Днепр, Украина, e-mail: borvvin@gmail.com; tm.i.sm.master@gmail.com; 251277ved@gmail.com

Цель. Разработка модели зубчатой передачи, которая учитывает податливость опоры шестерни, для исследования влияния поперечных колебаний на динамику зубчатой передачи в целом.

Методика. Расчетная схема составлена с помощью метода сосредоточенных параметров. Исследование динамики системы осуществляется методами теории колебаний систем с двумя степенями свободы. С использованием приближенных методов теории колебаний и алгебры определены амплитуды колебаний системы. Результаты численного интегрирования уравнений динамики сопоставляются с экспериментальными данными.

Результаты. Исследовано современное состояние вопроса касательно моделей зубчатых передач, учитывающих взаимное влияние крутильных и поперечных колебаний. С помощью метода сосредоточенных параметров создана расчетная схема для расчета динамики зубчатой передачи на податливой опоре. Исследована амплитудно-частотная характеристика открытой зубчатой передачи барабанной мельницы МШРГУ $4500 \times 6000$ с учетом податливости вала-шестерни и подшипников. Показано, что крутильные колебания шестерни и поперечные колебания приводного узла имеют взаимное влияние. Модели динамики высоконагруженных зубчатых передач дают значения собственных частот со значительной погрешностью. Определены области возможного силового резонанса в приводном узле открытой зубчатой передачи барабанной мельницы. Определены причины повышенной виброактивности механических систем приводов некоторых мельниц и причины роста виброактивности во время эксплуатации. Показано, что повышение виброактивности приводного узла мельницы вследствие периодического действия сил, действующих с зубчатой частотой, маловероятно. Определены рациональные способы уменьшения виброактивности существующих мельниц за счет смазывания и повышения твердости рабочих поверхностей зубьев шестерен.

Научная новизна. Разработана методика определения резонансных областей зубчатых передач с учетом взаимного влияния крутильных колебаний шестерни и поперечных колебаний опоры шестерни.

Практическая значимость. Определены области возможного силового резонанса в приводном узле открытой зубчатой передачи барабанной мельницы МШРГУ $4500 \times 6000$.

Ключевые слова: зубчатая передача, собственная частота, виброактивность, резонанс, барабанная мельнииа

Рекомендовано до публікації докт. техн. наук I. М. Кузяєвим. Дата надходжкення рукопису 30.06.17. 